European journal of American studies

Special Issue: Race Matters: 1968 as Living History in the Black Freedom Struggle

\title{
Black Power on Campus: Challenging the Status Quo in Chicago '68
}

\section{Caroline Rolland-Diamond}

\section{(2) OpenEdition \\ Journals}

Electronic version

URL: https://journals.openedition.org/ejas/14321

DOI: $10.4000 /$ ejas. 14321

ISSN: 1991-9336

Publisher

European Association for American Studies

Electronic reference

Caroline Rolland-Diamond, "Black Power on Campus: Challenging the Status Quo in Chicago '68", European journal of American studies [Online], 14-1 | 2019, Online since 29 March 2019, connection on 08 July 2021. URL: http://journals.openedition.org/ejas/14321 ; DOI: https://doi.org/10.4000/ejas. 14321

This text was automatically generated on 8 July 2021 .

Creative Commons License 


\title{
Black Power on Campus: Challenging the Status Quo in Chicago ' 68
}

\author{
Caroline Rolland-Diamond
}

1 Scholarly and popular accounts of Chicago in 1968 bring to mind images of violence that have overshadowed all forms of social and political activism in the city at that time ${ }^{1}$. During the night of April 4, as news of Martin Luther King Jr.'s assassination spread, the West Side erupted into what had become a usual scene of black desperation. Before the night had ended, burned cars, looted stores, broken bottles, rocks, and street battles between thousands of black residents and overwhelmed police officers provided the local version of the expression of anger that took center stage in black ghettos across the nation. A few months later, the city experienced another spell of violence when the Chicago Police Department brutally clashed with antiwar protesters outside the Hilton hotel during the Democratic National Convention. These two stories prominently appear in many Sixties retrospectives, usually after a brief mention of the 1966 Open Housing campaign led by King as part of his attempt to "bring the movement north." ${ }^{2}$ But they usually are told separately, intersecting only insofar as civil rights activists, young black "rioters," and New Left activists all ran into the muscular Chicago-style politics of law and order under the all-powerful mayor Richard J. Daley.

2 In the vast literature on the Sixties, a relatively small number of studies focus specifically on student mobilization, and the Windy City seldom makes the list of American cities affected by major college student protests. The first wave of Sixties scholarship emerging in the late 1980s and 1990s dealt almost exclusively with white New Left students, often members of Students for a Democratic Society (SDS). These studies have provided us with rich accounts of student radicalization and of the role of the growing antiwar movement in this process. Since that time, other scholars have expanded our knowledge of the connections between the New Left and the counterculture, the rise of the underground press, and the role student journalists played in the links between the New Left, the labor movement, and the civil rights 
movement. ${ }^{3}$ Yet, most accounts have explored the Movement as it unraveled at prestigious universities, such as Columbia University and the University of California at Berkeley, or in a specific college town, such as Madison, Wisconsin and Austin, Texas. ${ }^{4}$ Neither the University of Chicago (UC) nor Northwestern University (NU) in the leafy suburb of Evanston to the north-Chicago's most elite universities-were the site of spectacular confrontation between student activists and the administration that lasted long enough to make national or international headlines.

Since the 2000s, scholars have examined the mobilization of black college students on a series of campuses from Cornell University to the University of Pennsylvania, Columbia University, San Francisco State College, and Merritt College in Oakland. ${ }^{5}$ Again, Chicago has only appeared as second fiddle in this new wave of studies. Martha Biondi's Black Revolution on Campus stands as the only work covering the Chicago scene with its account of the short-lived black student protests that took place at Northwestern University in May 1968, and at Crane Junior College (today Malcolm X College) on the city's Near West Side in $1969 .{ }^{6}$ Taken together, these stories are invaluable to documenting the various faces of Black Power on campus and to historicizing the hopes and expectations that surrounded the creation of the first Black Studies departments across the country. They are also key to understanding, in the words of historian Ibram Rogers, how this wave of student activism constituted a "social movement in its own right." As Donna Murch's Living for the City and Jakobi Williams's From the Bullet to the Ballot have shown, black student activism should not be seen as a mere product of larger campaigns for civil rights and Black Power but actually played a crucial role in the invention of Black Power. ${ }^{8}$ Adopting a similar approach, this article takes black student protesters seriously as full-fledged activists. Yet it argues that focusing exclusively on the actions of African American students on campus obscures other local mobilizations led by African American college students in collaboration with Latinx and white radical students, as well as non-student activists to transform their universities and their city.

4 This article bridges the gap between the growing scholarship on the local Black Power movement that focused on the mobilization of neighborhood activists, and the more limited body of literature on Black Studies and Black Power on campus. It shows how black college students in Chicago acted in close collaboration with other activists, on and off campus, to alter the racial and social status quo in Daley's Chicago. By examining the role black college students played in a citywide movement, challenging racial and social inequalities in the late 1960s, this article illuminates the connections that existed between student activism and neighborhood politics in the urban North. It argues that black college students played a key role in maintaining the interracial collaboration that was necessary for the radical challenge social and racial justice activists tried to create in Daley's Chicago. It tells a story that adds college students alongside radical community organizers, welfare mothers, labor unionists, and grassroots politicians to the list of Black Power activists who tried to reinvent the meaning of American democracy in the long Sixties.

\section{Black Power on Campus}

5 Many scholars have shown that Black Power did not suddenly emerge in 1966 when Stokely Carmichael, the new chairman of the Student Nonviolent Coordinating 
Committee (SNCC), uttered these magic words in Greenwood, Mississippi, but rather evolved years before out of the mobilizations of radical labor activists, black nationalists, low-income mothers, preachers, and ex-Communists. Chicago is no exception. To anyone who cared to look, Black Power sensibilities were very visible on the city's West and South Sides by the early 1960s. Grassroots organizations such as the militant protest group The Woodlawn Organization (TWO) were already discussing issues of black pride, empowerment, and self-determination that would become standard Black Power demands in the second half of the decade. African American parents who participated in the massive Freedom marches and one-day boycotts that kept thousands of black pupils away from school (225,000 on October 22, 1963, about 124,000 in February 1964, and about 100,000 in June 1965) to protest overcrowded and dilapidated schools demanded both "equality now" and "community control" of neighborhood schools. To them, racism pervaded Chicago's education and housing policies under Mayor Daley. As evidence of this racism, superintendent of Chicago public schools Benjamin Willis decided to shorten the school day for black students, institute double shifts and install temporary classroom trailers (quickly dubbed "Willis Wagons") instead of transferring black students to nearby white schools with empty classrooms. Regaining control of the schools, they believed, was the only way to ensure quality education for their children. ${ }^{9}$ Meanwhile, since 1964 the militant group ACT, founded by Lawrence Landry, had been organizing regular protests against all-white fire-stations, as well as police harassment and brutality in black neighborhoods. ${ }^{10}$

6 Few college students were involved in ACT in the first couple of years of its existence, but as the group spread its message of "self-determination, self-respect, and selfdefense" among poor black residents, it started to attract a number of students determined to use their college education to make a difference. ${ }^{11}$ Black Power sensibilities fully reached Chicago campuses in 1966 in the aftermath of the failed Open Housing campaign led by Martin Luther King, Jr. and the Southern Christian Leadership Conference (SCLC) to desegregate housing in the city. The empty promises of the "pact" signed by King and Mayor Daley to end the protests left many activists involved in the Coordinating Council of Community Organizations (CCCO), the umbrella organization of community groups involved in the Chicago Freedom Movement, steaming with anger. ${ }^{12}$ Many black college and high school students had participated in the Chicago Freedom Movement, and their disillusionment led to impatience with the slow pace of change in the city and in its schools and universities, in a context marked by a larger movement for student power and the radicalization of the black movement for justice and equality. ${ }^{13}$

7 As the Black Power message of racial pride, nationalism and empowerment resonated with an increasing number of black youths, protest started to brew on campuses across the city. At the University of Illinois at Chicago Circle (UICC), the local branch of the University of Illinois that opened in 1965, as well as at Loop Junior College, Wilson Junior College, and other campuses of the Chicago City Colleges, activists formed chapters of the Afro-American Student Association (AASA). Members of this new organization, which was modeled after the black student unions created around the same time in other parts of the country, shared their views on readings by such thinkers as Frantz Fanon and Malcolm X, and discussed what they believed was their unfair treatment as black students in white-dominated universities. ${ }^{14}$ Such discussions led to demands for support and recognition by the administration and faculty. Through 
1966 and 1967, members of these chapters directed most of their energy at raising their student consciousness about the status of minorities on campus. Yet their concerns were never limited to university issues, and they tried to rally other youths to the larger cause of black liberation and empowerment in the city. At a time when black communities across the nation were divided over strategy-between the more moderate approach favored by organizations like the Urban League and the National Association for the Advancement of Colored People and the more confrontational Black Power one supported by SNCC and the Congress of Racial Equality (CORE)-these young radicals highlighted the crucial role black college students had to play within the community. ${ }^{15}$

James Harvey, a student at Wilson Junior College (today Kennedy-King College) in the South Side neighborhood of Englewood, was one of them. An active participant in the organization ACT, he helped to organize a "Black Power Forum" on campus on December 7, 1966. While this "forum" was only attended by about twenty people, the discussion reflected the new ideas that were circulating among a small group of black college students-members of ACT and the local AASA chapter. Fully aware of the strong resistance mustered by "Daley's Democratic machine" to any challenge to its power, black college activists picked up an idea explored around the same time by the Chicago Freedom Movement: reaching out to the members of the powerful South Side gang, the Blackstone Rangers, to unite them with college students and ghetto youths in Black Power bloc around the objective of community empowerment. Considering the balance of power in Chicago, only such an alliance had the potential to effect social change in the two massive South Side and West Side ghettos. Particularly promising in their eyes (and worrisome in the eyes of the undercover police officer who attended the meeting) was the Rangers' recent politicization. The gang was planning to run an aldermanic candidate for the next municipal election to challenge the local candidate handpicked by the Daley machine, as well as to open businesses to "keep the money in the community." Such attempt at "black unity" reflected the rising militancy of the larger black movement for justice and equality that was hardly unique to Chicago: a pamphlet entitled "Revolutionary Nationalism and the Afroamerican Student" that circulated on campuses throughout the Midwest advocated a similar alliance of students, residents, and gang members. ${ }^{16}$

In 1967 and 1968, efforts to link student activism and community empowerment intensified. The Afro-American Student Association sought to mobilize black college and high school students in coordination with ACT and grassroots West Side and South Side community organizations. During their meetings, the young activists discussed numerous issues ranging from the rights of African Americans in the war in Vietnam to school inequalities, urban renewal programs, and police harassment. ${ }^{17}$ The group Black, Active and Determined (BAD) organized several operations on campuses to alert their "brothers and sisters" to the necessity of mobilizing actively on and off campus to challenge the racial and social status quo. ${ }^{18}$ In June 1967 at the University of Chicago, the newly formed Society for the Promotion of Lobbying in the Interest of Black Students (SPLIBS) submitted a list of demands to the administration: increasing the number of black undergraduates and setting up academic support programs for both prospective students from nearby high schools and UC students. ${ }^{19}$ Four months later, head of SPLIBS Linda Murray directly attacked the university for being racist and 
displacing poor black residents from Woodlawn "the same way it had already done in Hyde Park."20

10 Like their counterparts in other cities, Chicago's black students, influenced by Malcolm X's speech on Afro-American history and by Stokely Carmichael and Charles Hamilton's views on Black Power, began to forcefully demand change in curricula and admissions as a first step toward their "liberation." Echoing Malcolm's call to use "any means necessary" to achieve their goals, they threatened the administration of their respective schools with disruption if their demands were not met. Confronted with this new militancy, most universities and colleges were forced to listen as they grew concerned about their ability to avoid disruptions to their operations. They were not the only ones worrying. Black student activism was closely monitored by members of the Chicago Police Red Squad as it was no longer limited to a few colleges and universities. In the fall of 1967 , black high school students across the city started to voice their anger at what they considered to be conditions of racial discrimination visited upon them by white students, teachers, and school administrators. And, like their older peers in college, they drew a direct link between their "oppression" at school and the way the overall "white power structure" operated in Chicago under Mayor Richard J. Daley. As these students lived at home in the city's impoverished black neighborhoods, the connection was not hard to see. And like black college students, they were determined to make their voices heard.

11 On November 22, 1967, the Chicago Sun-Times covered several incidents of "school unrest" that escalated into violence on the city's Near North Side. The series of incidents started at Waller High School, a school in which black students represented just under $50 \%$ of a total of about 2,400 students and Puerto Ricans another 5-6\%. After a black student claimed to have been pushed around by white students, hundreds of his fellow schoolmates took to the streets to demand respect. The protest escalated when the school principal called the police, prompting the youth to go into the nearby housing project for support. After a clash with the police, protest broke out at Cooley High School, where 1,000 out of the school's 1,700 students walked out against police harassment in solidarity with Waller students. Further south, at Englewood High School, a school listed as 99.9 \% black, 400 students protested the dismissal of Owen Lawson, a teacher accused of "over-emphasizing Negro history," and threw bottles at the police. Two years after the last school boycott, the issue of school community control was still hot. Private schools were not exempt from this wave of protest: at nearby Mendel Catholic High, a school with only 100 black students out of a total of 1,400, African American pupils charged "mistreatment by faculty and other students" and demanded that "Negro achievement be recognized in Mendel's history classes," that the school hire black teachers, and that it cease its "unfair grading" of black students. ${ }^{21}$ On February 21, 1968, on the third anniversary of Malcolm X's assassination, students from Calumet High School and Hyde Park High School clashed with their school administration and the police when they tried to commemorate the slain activist and his legacy. They circulated a leaflet extolling Malcolm X and Black Power at fifteen high schools with a high or substantial number of black students, encouraging a significant number of students to walk out.22

Meanwhile, college students continued to organize. In January 1968, Black students at UICC staged an all-night sit-in at the administration building to protest both the beating of a black student of Dominican descent by the campus police and the larger 
discrimination they faced at the two-year old public institution. They published a pamphlet denouncing "repression" and calling for "student control of student affairs." While the university's agreement to open dialogue and investigate the alleged beating temporarily defused the situation at UICC, mobilization continued. In February, after three young men were shot and killed on the campus of South Carolina State University in Orangeburg during a civil rights protest, black students from Crane Junior College on the Near West Side of Chicago held a funeral march in the neighborhood. In the previous two years, the organizing energy of Stan Willis, Robert Clay, and Henry English, all working-class students from the area, had turned Crane into a hotbed of black power and community activism. Using the Afro-American History Club they had founded in 1966 as a platform to invite black nationalist speakers on campus, they advocated for a new curriculum and the recruitment of more black teachers and administrators in order to "make Crane intellectually and socially relevant to the community as a whole." ${ }^{23}$ On March 6,1968 , the Black Conscious Committee, composed of black students from Roosevelt University, met to discuss the best ways to "make black people more aware of their status and role in the white community." As a first step towards mobilization, the group recommended that "Black people should be more cognizant of current black orientated literature, magazines, and the work of black brothers." ${ }^{24}$ Like their peers at other educational institutions in the city, the main concern of Roosevelt's black students was the "community," and they advocated the need for "Black control of Black schools in Black communities." 25

The same year, UICC, Roosevelt, and Crane students actively participated in the creation of the Black Student Congress with representatives from thirteen other Chicago colleges. Formed to "organize Black students for liberation," the Congress issued a 17-point "statement of purpose." The activists mixed what had by then become traditional black campus movement tropes, such as demands that the "curriculum of [their] respective colleges and universities be re-oriented for Black People with Black teachers for a Black Studies program," and for "the establishment of a Black educational institution for Black people," with declarations of support to "all revolutionary movements of non-white peoples in their struggle against oppression," and "the right of armed struggle" against "the racist police state." The statement concluded with an ominous call to "maintain maximum ability to obtain our goals, and defend our people by any means necessary." ${ }^{26}$ The Black Power storm had fully hit Chicago campuses.

\section{Challenging the War, Challenging the City}

The community orientation of the Black Power movement on Chicago campuses made the growing mobilization of black students very worrisome to municipal authorities. Since the city had won the bid to host the August 1968 Democratic National Convention, Daley had insisted that nothing would come to disturb the proceedings. Selling the image of Chicago as a racially calm city in contrast to other cities like New York, Los Angeles, Detroit, and Newark that had been hit by devastating outbreaks of violence, the mayor of Chicago had downplayed the 1966 Division Street and West Side uprisings as mere "juvenile disturbances," and repeatedly claimed that all Chicagoans loved their city. While the Kerner Commission report on the 1967 urban rebellions highlighted the responsibility of "white America" in the making of the ghetto, Daley 
did not hesitate to claim that since "there was no ghetto in Chicago," no trouble was to be expected. ${ }^{27}$ As for the "outside agitators" who intended to "harass the convention," they were warned that the police were ready to stop them. Yet, as the mayor fully knew, there was no shortage of homegrown "agitators" and "rioters." To make matters worse, this diverse and growing group seemed determined to join their forces.

On the South Side and West Side, Chicago Freedom Movement activists continued to press for justice and equality in education and housing, and were increasingly adopting the militant tone of Black Power activists. While Daley's reelection in 1967 for his fourth term as mayor left many disillusioned about their ability to challenge the Democratic machine, the announcement of a desegregation plan for Chicago public schools by the new Superintendent of Schools, James Redmond, who replaced Willis in 1966, revived mobilization. Adopted under pressure following the Coordinating Council of Community Organizations (CCCO)'s complaint that the city's school system violated Title VI of the 1964 Civil Rights Act, the federally-mandated plan included a very controversial busing plan to alleviate overcrowding in black schools. While the local black community was divided over the meaning and potential effects of the busing plan, the strong resistance opposed by white parents to its implementation galvanized black activists. ${ }^{28}$ They joined the chorus of voices, on and off campus, denouncing the role of the city in maintaining racial inequality and fueling racism through its educational and urban renewal policies.

Not all the opposition was directed at the Daley administration. Indeed, the war in Vietnam attracted its share of protesters, but because the Democratic National Convention was going to take place in Chicago, the mayor took any antiwar activity as an attack against him. The antiwar movement had steadily developed on Chicago campuses since 1965, and included activists from SNCC, Students for a Democratic Society, the Student Mobilization Committee to End the War in Vietnam (SMC), the Chicago Peace Council (CPC), and the Chicago Area Draft Resisters (CADRE), an umbrella group of people and organizations who opposed the U.S. Selective Service System. While protest activities were often dominated by white college students, black opposition to the war was widespread. Galvanized by their awareness of the racial inequalities of the draft system and by their outrage at the repression world heavyweight champion and Nation of Islam member Muhammad Ali faced when he refused his induction, many black students publicly denounced the war as "brutal and racist." They were not the only ones doing so. On March 25, 1967, during his first appearance at an antiwar march, Martin Luther King also came out forcefully against the war. After leading 5,000 people down State Street with Al Raby of the CCCO, King told the crowd that he opposed the war because it was immoral, racist, and took money and attention from War on Poverty programs. This declaration reflected King's progressive radicalization since the days of the Open Housing Campaign and the "pact" with Daley. As the SCLC leader also increasingly denounced the economic inequalities that prevented true progress for black Americans and advocated for a guaranteed income for all, he warned the nation that the stakes were high. In the title of what became his last book, he asked "Where do we go from here: chaos or community?" 29

While King did not convert to Black Power, his opposition to the war and his insistence on the necessary focus on community empowerment resonated with young black activists in Chicago, and encouraged them to mobilize against the upcoming convention alongside grassroots activists. Black students became more vocal against 
the war. Robert "Bob" Brown, a former CORE activist who had been elected the regional chairman of SNCC in 1967, participated in many antiwar meetings and rallies alongside white activists, and was often heard leading chants of "Hell, No, We Won't Go!" 30 On January 27, 1968, the National Black Anti-War and Anti-Draft Union, a group of seventy blacks who had just formed a separate caucus during the Student Mobilization Committee's national conference at the University of Chicago, announced that it planned to join the April International Days of Protest against the war. James Harvey was selected to be the new group's regional chairman for Chicago. ${ }^{31}$ Shortly afterwards, famed black comedian and local civil rights activist Dick Gregory declared that he intended to organize daily marches in Chicago starting in May in an effort to move the convention to another city and "to embarrass Chicago into improving housing and economic conditions for Negroes." ${ }^{32}$ The 36 year-old was no longer exactly young himself, but his popularity among students guaranteed that his call would be followed by many black youths.

The explosion of the West Side on April 5, 1968, following the news that King had been assassinated in Memphis, provided a blatant rebuttal to Daley's claim that there was no ghetto in his city. The uprising began when high school students clashed with the police. The students had started marching from one school to the next to mobilize fellow students to walk out in some kind of improvised tribute to King. Before order could be restored, nine people had died and large swaths of the West Side had been leveled by fires. While Daley first tried to blame "black nationalists" and "outside agitators" for the outbreak of violence, it was clear to everyone that the West Side explosion was the result of "pent-up frustrations and grievances," and that it had taken place against a backdrop of poverty, segregation, and despair. ${ }^{33}$ For the mayor, though, the first order of business was not to address these issues, but to restore order and make sure no similar event would happen again until the convention. To this end, one week after the events, he ordered the Chicago Police Department to "shoot to kill arsonists" and "shoot to maim looters."

The stakes suddenly changed for black activists who had been mobilizing for change in the city. They were ready to use the attention the convention was going to bring as an opportunity. While Black Power activists' call for self-defense on and off campus took on greater relevance, Dick Gregory cancelled his plans to march in the city and encouraged every black Chicagoan not to participate in the convention protest in order to avoid possible bloodshed. As if to confirm his dire predictions, the April 27 antiwar parade and rally turned violent when the police tried to prevent the crowd numbering about 5,000 people from approaching the Civic Center, resulting in 50 people arrested and 15 others wounded. ${ }^{34}$ Activists all over the city drew two lessons from the April events: they needed to carefully weigh the possible costs and benefits before launching a protest and, considering the balance of power, the radical activist community needed to close ranks more than ever.

\section{Closing Ranks Against the Daley Machine}

However, in the Black Power era, unity was not easy. On campuses where Black Power sentiments were strong, the key words were nationalism and separatism. For white radical students who had been fighting side by side with black students since the early 1960s, the growing appeal of a separatist rhetoric had created a challenge. Everywhere 
around the nation, white radicals had been forced to design new strategies and to consider the possibility that their approach, too, was marked by racism, albeit unconscious or involuntary. In its "Declaration on Racism" and its "Resolution on SNCC" adopted by the SDS National Council of June 18, 1966, SDS had declared its support of Black Power as a "strategy for social change and a mode of organization" in the wider black ghettoes' struggle for survival, while recognizing the "enormous problems that ha[d] been raised by the emergence of black nationalism within the movement." Highlighting the connections between the black rebellion in the American ghettos and the fight against imperialism abroad, SDS officials had then concluded: "We have a special responsibility to fight racism among our own white population. In the context of that struggle against racism in the white population we will be able to aid the struggle for black survival and for black liberation in every way we can." ${ }^{35}$

One way to provide such help was to become involved in local efforts to empower black, Latinx, and working-class white residents in their struggle to be heard on issues such as the impact of the city's urban renewal plans and universities' expansion plans on their neighborhoods. Such efforts were not new. In November 1965, the University of Chicago "Friends of SNCC" chapter had organized a series of weekly seminars to encourage students to support SNCC's activities down South, as well as to engage in community organizing in North Kenwood and in Chicago's Hispanic neighborhoods to help people "gain their civil rights." ${ }^{36}$ In the context of rising Black Power sensibilities, the dominant mood among activists became more radical. On November 15 and 16, 1966, the Conference on the City and the University (CCU) organized a two-day event on the "Crisis in the City" at the University of Chicago. Seeking to raise greater awareness of the problems faced by neighborhoods such as Woodlawn, the panel discussion brought together the famed radical radio host Studs Terkel, Al Raby, Florence Scala, a West Side resident and leader of the movement opposing the development of a University of Illinois at Chicago Circle campus in the HarrisonHalsted area, and Clark Kissinger, former SDS leader active in the Committee for Independent Political Action (CIPA), a local organization aimed at challenging local Democratic candidates handpicked by the Daley machine. Attended by a large crowd of students, the "Crisis in the City" conference discussed the "Chicago school system, urban renewal housing in Chicago, youth in the ghetto, and the politics of fighting slums." 37

The local activists in the Chicago Freedom Movement set up a "School of Community Organizing" (SCO) in the spring of 1967. "Needing 'hard' information on urban renewal, public housing, welfare, health facilities, social welfare agencies, census, property ownership," the Chicago Freedom Movement turned to college students. Black, white, and Latinx volunteers from various campuses were asked to help gather "data on the rules and regulations of existing public aid agencies, voting records of incumbent politicians, graphical illustrations of the financial power structures within the Chicago ghettos, and details on present and contemplated plans for Chicago Urban Renewal." They were trained during two very intense ten-day workshops in March and April of 1967, with the participation of Rennie Davis of the local SDS program called JOIN (Jobs or Income Now), and of Al Raby of the CCCO. A pamphlet describing the initiative explained that "political and economic power for the poor must become working objectives" and that "staff and resources must be redirected toward creating and strengthening organizations of Negro, Spanish, and white poor." While the research 
was conducted by college students, the school was largely overseen by community organizers with the objective to "recruit, train, and place some twenty to thirty new organizers in the city every three months." ${ }^{38} \mathrm{~A}$ few months later, the School of Community Organizing organized a "free university" in Chicago to continue the research and data collection effort. ${ }^{39}$

Yet, in spite of these initiatives, persistent racial tensions threatened to undermine the radical activist community. At the University of Chicago, SPLIBS kept its meetings closed to white students-even a local student newspaper journalist who wanted to report on their discussions. Separatism was also on the rise in the student antiwar movement. ${ }^{40}$ When in January of 1968 black members of the Student Mobilization Committee announced at a conference at the University of Chicago that they were forming a separate "Black caucus," their decision was immediately supported by Latinx students. ${ }^{41}$

Indeed, Latinx students were also organizing at that time. In Chicago, most Latinx students were either of Puerto Rican or Mexican descent. Some student activists decided to join the Latin American Defense Organization (LADO), a local civil rights radical organization formed in the barrio around Division Street and Damen Avenue after the June 1966 uprising in that neighborhood to defend the population against "racism, discrimination, police violence, economic exploitation, and hard living conditions." ${ }^{42}$ On the campuses of the University of Illinois at Chicago Circle, Loop Jr. College and several high schools in the city, most Latinx students joined the Organization of Latin American Students (OLAS) and made similar demands for recognition and respect as those submitted by their fellow black counterparts. In a city as segregated as Chicago, the appeal of nationalist and separatist discourses among black and Latinx students was not surprising. ${ }^{43}$ Most minority students did not live on campus but commuted to school from their neighborhood, and their views were informed by the growing mobilization for justice and equality in the city. They were keenly aware that their status as students granted them with a specific responsibility to use the skills and knowledge they acquired to the benefit of the community. While their immediate goal was to transform their universities and colleges, they ultimately worked for the community. Yet, precisely because of this community focus, black and Latinx students were also aware that they needed to make alliances if they wanted to stand a chance to improve the living conditions of the residents of their neighborhood in Richard Daley's Chicago. They thus continued their mobilization for Black/Brown Power, while remaining open to possible support from white student radicals, as long as they stayed in the driver's seat.

The tensions that followed the April West Side explosion increased in the upcoming months leading to the Democratic National Convention (DNC). As the city made it clear that any disruption during the DNC would be met with force, local black and Latinx student activists were faced with difficult questions: Should they participate in the antiwar activities and seize the opportunity to get heard as "the whole world will be watching"? Would their voices be heard or drowned in the midst of the crowd? Should black and brown students continue their local activities and stay away from an event that increasingly seemed to be heading toward a violent clash between the police and demonstrators? While all were opposed to the war and saw it as an illegal, immoral, and racist war that captured millions of dollars that should have been spent on War on Poverty programs or other grassroots initiatives, many black students believed that the 
likely clash between protesters and the police made participation not worth the risk. They could be more useful to the cause of black community empowerment if they continued their work along with other local activists to force the city to address community concerns such as education, employment, housing, health, and police harassment. Black Power activism increased on local campuses.

Like their peers on Chicago campuses, African American students at Northwestern University (NU) also felt that change was necessary. Although their number had more than tripled since 1966, when Northwestern established a specific program to increase black enrolment from some fifty students to about one hundred and sixty, black students remained a very small and isolated minority on campus, and many complained of discrimination..$^{44}$ On May 3, 1968, around $7 \mathrm{am}$, they took action. As one student told the guard watching the entrance to the Bursar's Office that he needed to enter to pick up a form, loud voices rose up nearby, prompting the guard to leave his post. Within minutes, a group of one hundred students, members of the black student organization, For Members Only, had taken control of the building. Their leader, James Turner, presented the administration a petition listing several demands: that Northwestern University recognize its institutional racism, enroll more black students, increase financial aid, create dedicated student housing for black students, establish an African American studies curriculum, and desegregate the university's real estate holdings in Evanston. ${ }^{45}$

A tense standoff followed. Many in the Northwestern community believed their alma mater ranked high among the racially progressive forces in the Chicago area; they were shocked by the accusation of racism. Moreover, responding to the list of grievances presented in April by representatives of For Members Only and the Afro-American Student Union, Northwestern had already agreed to create a separate meeting room for black students by the next academic year. ${ }^{46}$ Dean of students Roland Hinz, the only white person allowed in the office the weekend of the Bursar's office takeover, went in to negotiate. Thirty-eight hours later, the administration agreed to a large number of the students' demands, thus ending the confrontation. It promised to reserve student housing for African Americans, increase student participation in policy matters, and create what is today the university's Department of African American Studies.

The "Northwestern pact," as it became known, divided the NU community. While some radical students deplored the fact that $\mathrm{NU}$ had made no concession concerning its real estate holdings in the city of Evanston, most were relieved by the outcome and lauded the administration for finding a way out that avoided both an occupation over several days similar to the one that had taken place at Howard University in Washington in March, and the stalemate and violent escalation that had paralyzed Columbia University in New York City a few weeks before. ${ }^{47} \mathrm{~A}$ vocal minority denounced Northwestern's "capitulation" to black demands. ${ }^{48}$ To the students, faculty members, local politicians, and members of the general public, who wrote indignant letters to the trustees of the university, to the city's three major dailies, and to the local student newspaper, Northwestern University was the latest institution to succumb to the Black Power storm that had been gaining strength in Chicago since 1966 and showed no sign of abating. ${ }^{49}$ Indeed, on May 4, 1968, the same day that Northwestern protest ended, three hundred students from the University of Illinois at Chicago Circle (UICC) and members of the Concerned People of the Westside met on campus to discuss the university's latest 
expansion plan. Soon, the heated discussion turned to how necessary it was for the local black community to get a greater voice both on campus and in the HalstedHarrison neighborhood where the campus was located. On May 10, some sixty black students from the Illinois Institute of Technology sent an ultimatum to the administration: they demanded an end to the police harassment of students and local residents, a reform of disciplinary procedures, free access to campus facilities for people from the community, admission of more students from the surrounding high schools, and the creation of a black studies department. ${ }^{50}$ The following week, African American students from the private Catholic DePaul University threatened the school administration with violent protest if it did not create a Black Studies program, hire black faculty members, and put an end to the discriminatory practices of campus fraternities and sororities. ${ }^{51}$ On May 15, sixty members of SPLIBS seized control of the University of Chicago administration building to demand that the university enroll more black students, add courses on African American history to its curriculum, and stop expanding in the Woodlawn area until it found housing for the families it displaced ${ }^{52} \mathrm{~A}$ few days later, protests spread to Northeastern Illinois State College and Chicago State College. ${ }^{53}$

The May 1968 events marked a turning point in the way city officials responded to the black college student mobilization. Because of its location in midst of the South Side Hyde Park/Woodlawn/Kenwood area, the University of Chicago had been a regular provider of student activists in support of racial equality since the days the Congress of Racial Equality (CORE) was founded there by James Farmer in 1943. The rise of black student activism in the fall of 1967 and early 1968 could then be interpreted by the mayor's office as yet another example of student "agitation" at the South Side institution. But when traditionally conservative Northwestern University followed suit, the Daley administration was forced to recognize the growing appeal of Black Power rhetoric and to admit that no institution was protected against accusations of racism. It also came to terms with the idea that protest was growing in unprecedented ways across the city. New institutions that had remained relatively quiescent until then suddenly faced challenges, while others which had already been experiencing mobilization continued to be "attacked." Worse, while the city of Chicago was trying to recover from the April 4 West Side uprising, Black Power student talk of "ultimatums," "violence," and calls to use "any means necessary" to achieve their goals took on a new meaning. Particularly threatening to the Daley administration was the possible rapprochement between radical student activists, black, Latinx and white, and between these student activists and non-student grassroots organizers, or, to put it simply, between the campus and the ghetto.

31 Indeed, SDS members, who were very active both on Chicago community college campuses and at more prestigious universities like UC, Northwestern, DePaul, and Loyola, were also determined to work in support of black and Latinx students on and off campus. After the SDS National office had tried for awhile to promote studentworker alliances with very limited success, the student organization changed its position in 1968 as it continued its radicalization. It was no longer time to only resist "the system." Now was the time to organize for the revolution that was both upcoming and necessary. In this perspective, the SDS National Office, based on the West Side of Chicago, designed a new strategy of alliance with revolutionary black and Latinx youth groups under the name "Revolutionary Youth Movement": while black and Latinx working-class students would be the vanguard of the revolution, radical white students 
would provide them with all the support they needed, while continuing to organize their own community against racism. ${ }^{54}$ On the city's campuses, this strategy translated into more joint actions. At Northeastern Illinois State College, white radical students came out in solidarity with black students' demands and threatened their administration with further disruption if the school did not yield to Black Power demands for changes in the curriculum and admissions ${ }^{55}$ Meanwhile, members of the Organization of Latin American Students (OLAS) were trying to raise the consciousness of Latinx students by denouncing their economic, social, and linguistic problems, while developing strategic contacts with SDS, Vanguardia, another Latinx student group at UICC, as well as with the Afro-American Club at Loop Junior..$^{56}$ More threatening to the universities and to the municipal authorities were the joint student-community actions that continued against the expansion plans of universities such as UC, IIT, or UICC, which the activists tied to the city's overall urban renewal program.

While most black and Latinx youths had stayed clear from the protest during the Democratic National Convention, the violent confrontation that took place only confirmed to the young radicals that it was necessary to maintain multiracial coalitions. If the police were ready to launch what the official investigative report called a full-scale "police riot" to prevent any challenge to the existing balance of power in the city, activists of all backgrounds needed to coordinate their actions. ${ }^{57}$ While racial and class tensions surely existed between black, Latinx, and white student activists, the shared objective of effecting meaningful change in Chicago made it possible for a powerful multiracial coalition to develop. Contacts and collaborations had by then existed for over two years, in spite of the separatist appeal of Black Power, but they reached an unprecedented level when, by the end of 1968, Bobby Rush and Bob Brown of SNCC, along with twenty-year old Fred Hampton, formed the Chicago section of the Black Panther Party for Self-Defense. For Mayor Daley, who had been keeping a close eye on the rise of black nationalist organizations and student groups in the city, this creation did not bode well, especially as the local BPP soon announced that it intended to collaborate with other activist groups in the city. Daley was determined to prevent such an alliance "by any means necessary." He ordered the Chicago Police Department to launch an all-out assault on student activists, in collaboration with the FBI Counterintelligence Program (COINTELPRO), the Internal Revenue Service, and the Military Intelligence Group stationed in Illinois. While law enforcement agencies often competed with each other, in Chicago, they displayed an unusual level of collaboration toward the same goal. ${ }^{58}$

Bobby Rush and Bob Brown were already seasoned activists in spite of their young age, but Fred Hampton's activist record was even more striking: not only had he been active in the NAACP in Maywood, Illinois where he grew up, but he had already managed, as chairman of the West Suburban Youth Chapter of the NAACP, to successfully mobilize the 500 black students of his high school to demand more recruitment of black faculty and administrators, as well as better recreational facilities for Maywood poor black residents. Upon graduation from Proviso East High School, he enrolled in a two-year pre-law program at Triton Junior College in River Grove, Illinois while continuing to be an active leader of the NAACP Youth group. In 1968, he took classes at Crane Junior College and UICC, and decided that it was high time that a section of the BPP existed in Illinois, and particularly in Chicago..$^{59}$ 

well known, in part thanks to Jakobi Williams's book From the Ballot to the Bullet. During the winter of 1968-1969, Black Power student activism reached a new high. For instance, in February 1969, members of the Black Student Alliance (BSA) at Roosevelt University organized a series of class disruptions to teach Black Studies, and demanded the creation of a Black Studies Department that would be placed under their control, vowing to continue their action "by ANY MEANS NECESSARY." Similar actions took place at Crane Junior, Chicago State College, Southeast College, UICC, and the University of Chicago, as young activists became galvanized by the arrival of the Panthers. The disillusionment with the ability of the Chicago Freedom Movement to achieve its goals and defeat the Daley machine, as well as the self-defense rhetoric mixed with the paramilitary style and community focus of the Panthers, proved irresistible. By 1969, the Illinois Black Panther Party (ILBPP) was active in many high schools in the city and had established local chapters at Chicago State University, Crane Junior College, Illinois Institute of Technology, Northeastern Illinois University, Roosevelt University, UICC, Wilber Wright Junior College, and Woodrow Wilson Junior College..$^{61}$ Under chairman Fred Hampton's leadership, BPP members reinforced the existing alliances between white, Latinx and black youths on and off campus.

The "Rainbow Coalition" Hampton formed between the BPP, SDS, the Puerto Rican Young Lords, and the white working-class Young Patriots, created a formidable challenge to Daley. While the Panthers' free breakfast program, which fed over 2,000 children daily in Chicago, ensured the organization's popularity in the black ghetto, the Coalition's attempt at improving housing conditions for poor black, Latinx and white residents of the city, desegregating schools and recreational facilities, addressing the issues of high unemployment and poverty, providing health care facilities to the poor, and denouncing political corruption and police brutality, guaranteed that the Rainbow Coalition and its leader would be high on the list of the local authorities' "subversive forces" to be "neutralized." ${ }^{62}$ Sure enough, on Dec. 4, 1969, the Illinois State police killed Fred Hampton during a raid on his West Side apartment while the ILBPP chairman was sleeping in his bed. Another Panther, Mark Clark, was also killed. ${ }^{63}$

The Rainbow Coalition did not survive the death of Fred Hampton; it fell apart under strong racial and class tensions that were undermining it from the start. Nor did it exist long enough to fully test its ability to effect change in Daley's Chicago. Racial and social inequalities persisted fairly unchanged until Daley died in office in 1976. Yet the Rainbow Coalition and the other ad hoc multiracial student alliances that developed in Chicago from 1966 to 1969 show how most black student activists understood Black Power as a larger project, of which the transformation of the university was only one part. Ultimately, their goal was to empower the black community politically and socially on and off campus. To this end, Black Power student activists not only used ideas and tools developed outside the campus by grassroots activists to force the universities and colleges to change, but they also brought the rhetorical, research and analytical skills they learned in school to the benefit of grassroots Black Power activists in the neighborhoods. Their action thus highlights the deep connections between the student and non-student Black Power movements, making it impossible to understand them separately. While together these activists did not manage to immediately alter the status quo in Chicago, their mobilization and experience ultimately paved the way 
towards the future multiracial political coalition that elected Harold Washington as the first African American mayor of the city.

\section{NOTES}

1. See for instance David Farber, Chicago '68 (Chicago: University of Chicago Press, 1988); the movie "Medium Cool," by Haswell Wexler, 1969; and "The Sixties - The Years That Shaped a Generation," PBS Documentary, 2005.

2. Todd Gitlin, The Sixties: Years of Hope, Days of Rage (New York: Bantam, 1987) and Maurice Isserman and Michael Kazin, America Divided: The Civil War of the 1960s (New York: Oxford University Press, 1999) are two examples of such surveys of the Sixties. The SCLC's "northern campaign" plan is presented in Alan Anderson and George Pickering, Confronting the Color Line: The Broken Promise of the Civil Rights Movement in Chicago (Athens: University of Georgia Press, 1986), 160-207.

3. In addition to the classic G. Norman Van Tubergen, "The Student Press and Campus Unrest," Journalism Quarterly 47:2 (1970): 368-372, see John McMillian, Smoking Typewriters: The Sixties Underground Press and the Rise of Alternative Media in America (New York: Oxford University Press, 2011); Kaylene Dial Armstrong, How Student Journalists Report Campus Unrest (Lanham, MD: Lexington Books, 2018); and Errol Salamon, "The 'Free Press' of Unionized Journalists and Students: An Alternative Journalistic Collaboration." Journalism Practice 12:5 (2018): 565-584.

4. Stefan M. Bradley, Harlem v. Columbia University: Black Student Power in the Late 1960s (Urbana: University of Illinois Press, 2012); Doug Rossinow, The Politics of Authenticity: Liberalism, Christianity, and the New Left in America (New York: Columbia University Press, 1998); Matthew Levin, Cold War University: Madison and the New Left in the Sixties (Madison: University of Wisconsin Press, 2013).

5. Dikran Karagueuzian, Blow It Up!: The Black Student Revolt at San Francisco State and the Emergence of Dr. Hayakawa (Boston: Gambit, 1971); William H. Exum, Paradoxes of Protest: Black Student Activism in a White University (Philadelphia: Temple University Press, 1985); Richard P. McCormick, The Black Student Protest Movement at Rutgers (New Brunswick, NJ: Rutgers University Press, 1990); Donald Alexander Downs, Cornell '69: Liberalism and the Crisis of the American University (Ithaca, NY: Cornell University Press, 1999); Wayne Glasker, Black Students in the Ivory Tower: African American Student Activism at the University of Pennsylvania, 1967-1990 (Amherst, MA: University of Massachusetts, 2002); Joy Ann Williamson, Black Power on Campus: The University of Illinois, 1965-1975 (Urbana : University of Illinois Press, 2003).

6. Martha Biondi, The Black Revolution on Campus (Berkeley: University of California Press, 2012), 79-113. On the making of the first Black Studies departments, see also Fabio Rojas, From Black Power to Black Studies: How a Radical Social Movement Became an Academic Discipline (Baltimore: Johns Hopkins University, 2010).

7. Ibram Rogers, The Black Campus Movement: Black Students and the Racial Reconstitution of Higher Education, 1965-1972 (New York: Palgrave, 2012), 18.

8. Donna Murch, Living for the City: Migration, Education, and the Rise of the Black Panther Party in Oakland (Chapel Hill: University of North Carolina Press, 2010) and Jakobi Williams, From the Bullet to the Ballot: The Illinois Chapter of the Black Panther Party and Racial Coalition Politics in Chicago (Chapel Hill: University of North Carolina Press, 2013). Scot Brown in Fighting for Us: Maulana 
Karenga, the US Organization, and Black Cultural Nationalism (New York: New York University Press, 2003) similarly argues that California public universities and colleges played a crucial role in the rise of political radicalism in the 1960s.

9. Editorial, "WE ACCUSE! Benjamin C. Willis, Superintendent of Chicago Public Schools," Chicago Defender, August 16, 1963. Dionne Danns, Desegregating Chicago's Public Schools: Policy Implementation, Policy, and Protest, 1965-1985 (New York: Palgrave Macmillan, 2014), 14-15.

10. Andrew J. Diamond, Chicago on the Make: Power and Inequality in a Modern City (Berkeley: University of California Press, 2017), 181-186.

11. "Urge Poor in 8 Cities to Boycott Poverty War," Jet 28:15 (22 July 1965): 4; “Group Set "Black Power' Confab," Jet 30:24 (22 September 1966): 6.

12. Peniel Joseph, "Rethinking the Black Power Era," The Journal of Southern History 75:3 (August 2009): 707-716. On the Chicago Freedom Movement, see Anderson and Pickering, Confronting the Color Line; James R. Ralph, Northern Protest: Martin Luther King Jr., Chicago, and the Civil Rights Movement (Cambridge: Harvard University Press, 1993); Mary Lou Finley, Bernard Lafayette, Jr. et al. (eds.), The Chicago Freedom Movement: Martin Luther King Jr. and Civil Rights Activism in the North (Lexington: University of Kentucky Press, 2016), and Caroline Rolland-Diamond, Black America: Une histoire des luttes pour l'égalité et la justice (XIXe-XXe siècle) (Paris: La Découverte, 2016), 337-340. 13. William Van Deburg in New Day in Babylon: The Black Power Movement and American Culture, 1965-1975 (Chicago: University of Chicago Press, 1992, 2-11), has argued that Black Power activists drew their inspiration from student power protests and sit-ins that showed them that a small cadre of determined activists could shut down universities. The Student Against the Rank movement that took place at the University of Chicago in 1966 is a good example of this. For a detailed study of the links between student and community activism across racial lines, see Caroline Rolland-Diamond, Chicago le moment 68: Territoires de la contestation étudiante et répression politique (Paris: Syllepse, 2011).

14. On the emergence of black student associations on community campuses, see Murch, Living for the City, 71-116, and Peniel Joseph, "Dashikis and Democracy: Black Studies, Student Activism, and the Black Power Movement." Journal of African American History 88:2 (Spring 2003): 182-203.

15. The teach-in organized on January $26-27,1968$ by the Episcopal Society for Cultural and Racial Unity at the University of Chicago to discuss the topic "The Church Confronts Black Power" highlighted this division over Black Power: Ebony magazine editor Lerone Bennett declared "I'm deeply convinced that black power is the only alternative to disaster in this country," to a mixed crowd of students, clergy, and community activists. "Black Power Trends Examined," Chicago Maroon, 30 January 1968. See also "Wilkins Raps Separatism in Rights Drive," Chicago Tribune, 9 January 1968.

16. Investigator's Report, December 12, 1966, Box 203, Folder 1077 ACT, Red Squad Files, Chicago History Museum (hereafter CHM). "Revolutionary Nationalism and the Afroamerican Student," Vertical File, C.L. Negroes - Afroamerican Student Movement, Labadie Collection, University of Michigan Library. For more on the politicization of the Blackstone Rangers and the attempts at forging alliances between gangs, civil rights and Black Power groups, see Andrew J. Diamond, Mean Streets: Chicago Youths and the Everyday Struggle for Empowerment in the Multiracial City, 1908-1969 (Berkeley: University of California Press, 2009), 261-283.

17. Afro-American Student Association Press Conference and Demonstration, April 15, 1967 and Afro-American Student Association Meeting, April 21, 1967, Box 203, Folder 1077, Red Squad Files, CHM.

18. Black Active and Determined (BAD), "Brothers and Sisters Dig This," Box 216, Folder 1088 BAD, Red Squad Files, CHM.

19. "Supplementary Statement regarding the 1967 Proposals from SPLIBS," annexed to the letter sent by the Dean of Students Charles D. O'Connell, to the SPLIBS, May 15, 1968, Document 47, Box 211, Folder 1086 University of Chicago 1967-1971, Red Squad Files, CHM. 
20. "Murray Charges that Chicago is Racist Institution," Chicago Maroon, 31 October 1967.

21. “Teacher's Ouster Protested by 400 at Englewood High," Chicago Sun-Times, 21 November 1967; "School Unrest Leads to Near North Side Violence," "Waller Principal Blames Disturbance on Rumor," "23 Hurt, Nab 70 in Disturbances near Schools," Chicago Sun-Times, 22 November 1967; "School Gangs Fight Cops," Chicago Tribune, 22 November 1967; "Negro Groups Ask Teacher be Returned," Chicago Tribune, 27 November 1967. For a more detailed analysis on high school student protests, see Andrew Diamond and Caroline Rolland, "Au-delà du Vietnam: Chicago 1968 et l'autre mouvement étudiant-lycéen," Histoire@Politique. Politique, Culture, Société 6 (SeptemberDecember 2008).

22. "Malcolm X Day Rites Erupt in 2 City Schools," Chicago Tribune, 22 February 1968.

23. Quoted in Biondi, Black Revolution on Campus, 107.

24. Interview Report, Black Conscious Committee, March 8, 1968, Folder 1086 Roosevelt University (1) 1967-68, Red Squad Files, CHM.

25. Williams, From the Bullet to the Ballot, 68.

26. "Chancellor at U.I. to Hear Negro Gripes," Chicago Tribune, 20 January 1968; Surveillance report on "Black Power demonstration and sit-in at the UICC on Jan. 19, 1968", February 2, 1968, and "Repression," January 25, 1968, Box 212, Folder 1086 UICC 1967-1971, Red Squad Files, CHM; "Black Students of the University of Illinois at Chicago, Statement of Purpose, Box 211, Folder 1086 Southeast Campus Chicago City College, 1968-1970, Red Squad Files, CHM.

27. Mike Royko, Boss: Richard J. Daley of Chicago (Boston: E.P. Dutton, 1971), 130; Adam Cohen and Elizabeth Taylor, American Pharaoh: Mayor Richard J. Daley, His Battle for Chicago and the Nation (Boston: Little, Brown, 2000), 483. Kerner Commission, Report of the National Advisory Commission on Civil Disorders (Washington, DC: U.S. Government Printing Office, 1968).

28. Danns, Desegregating Chicago's Public Schools, 19-42.

29. Rolland-Diamond, Chicago le moment 68, 23-71. Martin Luther King, Jr, Where Do We Go from Here: Chaos or Community? (Boston: Beacon Press, 1967).

30. Joshua Bloom and Waldo E. Martin Jr, Black Against Empire: The History and Politics of the Black Panther Party (Berkeley: University of California Press, 2013), 131.

31. Interview Report, Student Mobilization Committee, January 27, 1968, Box 198, Folder 1064 B SMC 1968, Document 6, Red Squad Files, CHM; "Student Anti-War Strikes Set," Chicago Sun-Times, January 30, 1968.

32. "Convention Protest Canceled by Gregory," Chicago Tribune, 16 April 1968.

33. "Why the West Side Exploded," Chicago Sun-Times, 14 April 1968.

34. "Intelligence Report, April 24, 1968, Box 209, Folder 1086 IIT, Red Squad Files, CHM; "AntiWar Protesters Battle Police," Chicago Tribune, 28 April 1968; "Opinion of the People," Chicago Peace Council, The Struggles. I. A. 7 a, Alternative Literature Ephemera, Northwestern Library Special Collection.

35. "Racism Resolution," 1966, Students for a Democratic Society Papers, Series 3, Box 36, Folder 6, Wisconsin State Historical Society; "Resolution on SNCC," passed by the National Council of SDS, June 18, 1966, Spec/Labd 31399769 lab 1-7-99, Labadie Collection, University of Michigan Library.

36. "SNCC plans seminars," Chicago Maroon, 12 November 1965.

37. "Crisis in the City Reaches Campus with Two-Day Conference at Ida Noyes," Chicago Maroon, 15 November 1966.

38. Students against the Rank, Spring Work Project, February 22, 1967, Box 201, Folder 1068 SAR 1967-68, Red Squad Files, CHM; “Notes from Chicago: Beyond the Power Structure," The Movement 2:5 (May 1967): 12.

39. “A New ‘Free University’ Will Open This Summer," Chicago Maroon, 14 April 1967.

40. “SPLIBS Eject Maroon Writer," Chicago Maroon, 23 January 1968. 
41. Interview Report on Student Mobilization Conference at UC, Jan. 29, 1968, Box 198, Folder 1064B SMC 1968, Red Squad Files, CHM.

42. Surveillance Report, Vanguard, Dec. 5, 1967, Box 212, Folder 1086 - UICC, 1967-1970, Vol. 1, Red Squad Files, CHM. On the Division Street riot, see Diamond, Mean Streets, 295-296. See also Lilia Fernandez, Brown in the Windy City: Mexicans and Puerto Ricans in Postwar Chicago (Chicago: University of Chicago Press, 2012).

43. "Militant Organizers Dig In," The Movement 3:4 (April 1967): 3; "Chicago Chicanos," The Movement, 4:9 (September 1968): 7; Clara López, "LADO: The Latin American Defense Organization," Diálogo 2 (1997): 23-27.

44. "Develops Program to Recruit Negroes," Daily Northwestern, 4 March 1966.

45. Excerpts from the petition are reproduced in Immanuel Wallerstein and Paul Starr, eds. The University Crisis Reader. Volume One: The Liberal University Under Attack (New York: Random House, 1971), 297-298, 306-310.

46. "N.U. Negro Students to Get Meeting Room," Chicago Tribune, 30 April 1968.

47. On the Howard movement, see Lawrence B. de Graaf, « Howard: The Evolution of Black Student Revolt », in Julian Foster and Durward Long, eds., Protest! Student Activism in America (New York, William Morrow and Company, 1970), 319-344, and Armstrong, How Student Journalists Report Campus Unrest. On the Columbia events, see the Cox Commission Report, Crisis at Columbia: Report of the Fact-Finding Commission Appointed to Investigate the Disturbances at Columbia University in April and May 1968 (New York: Vintage Books, 1968), and Robert McCaughey, Stand, Columbia: A History of Columbia University (New York: Columbia University Press, 2003).

48. "434 Profs Commend N.U. Pact," Chicago Tribune, 7 May 1968; "N.U. Prof Assails Yielding to Students," Chicago Tribune, 7 May 1968; Rep. Michel Hits 'Shameful Surrender' to N.U. Minority," Chicago Tribune, 8 May 8 1968; "2 N.U. Profs Praise Pact with Negroes," Chicago Tribune, 11 May 1968; “N.U. Subcommittee OK's Demands of Negroes," Chicago Tribune, 12 May 1968.

49. "Black Separatism Move on the Rise," Chicago Tribune, 30 July 1968.

50. Petition and Information report, dated May 10, 1968, Folder 1086-IIT, Box 209, Red Squad Files, CHM; "I.I.T. Selects Committee to Hear Negroes," Chicago Tribune, May 8, 1968; "I.I.T. Replies to Demands by Negroes," Chicago Tribune, 28 May 1968.

51. "De Paul Gives Blacks Reply to 9 Demands," Chicago Tribune, 22 May 1968.

52. "Contingent Call for a Student Strike," May 1968, Box 1, Folder Student Activities, University of Chicago Special Collections; "Response by Dean of Students Charles O' Donnell to SPLIBS," May 15, 1968, Box 211, Folder 1086 UC 1967-69, Red Squad Files, CHM; "U. of Chicago Acts, Puts End to Sit-In," Chicago Tribune, 16 May 1968; "U. of C. White Students Await a Reply to Demands," Chicago Sun-Times, 17 May 1968.

53. "Call to a Confrontation," May 26, 1968, Box 206, Folder 1086 Chicago State College, and Interview Reports on "Black Caucus at NISC" May 20 and 27, 1968, Box 210, Folder 1086 NISC 1968-69, Red Squad Files, CHM.

54. "Revolutionary Youth Movement - Toward Unity of Theory and Practice", "Toward a Revolutionary Youth Movement," "Hot Town: Summer in the City," and "Revolution is a Rainbow Thing," SDS Radical Education Project, Series 3, Box 48, Folder 4, Students for a Democratic Society Papers, Wisconsin State Historical Society.

55. Surveillance Report on Demonstration - black students' sit-in at NISC, Nov. 25, 1968, Box 210, Folder 1086 NISC, Red Squad Files, CHM.

56. "Chicago Chicano," The Movement 4:12 (September 1968).

57. On the DNC confrontation, see David Farber, Chicago '68 (Chicago: University of Chicago Press, 1988), 165-207.

58. Rolland-Diamond, Chicago le moment 68, 257-298. 
59. Williams, From the Bullet to the Ballot, 55-56.

60. Rogers, Black Campus Movement, 1.

61. Williams, From the Bullet to the Ballot, 77.

62. Jon Rice, "The World of the Illinois Panthers," Jeanne Theoharis and Komozi Woodard (eds), Freedom North: Black Freedom Struggles outside the South, 1940-1980 (New York: Palgrave, 2003), 45-49; Williams, From the Bullet to the Ballot, 3-13.

63. Jeffrey Haas, The Assassination of Fred Hampton (Chicago: Lawrence Hill Books, 2010); Williams, From the Bullet to the Ballot, 167-190.

\section{AUTHOR}

\section{CAROLINE ROLLAND-DIAMOND}

Caroline Rolland-Diamond is Professor of American History and American Studies and Director of the Centre de Recherches Anglophones at the University Paris Nanterre, France. She specializes in post-World War II American and global history. She has written several books and articles on this era, with an emphasis on the black freedom struggle and student protest in the US, including Black America: une histoire des luttes pour l'égalité et la justice (XIXe-XXIe siècle) (Editions La Découverte, 2016), Révoltes et utopies: la contre-culture américaine des années 1960 (co-written with Andrew Diamond and Romain Huret, Editions Fahrenheit, 2012), and Chicago: le moment 68. Territoires de la contestation étudiante et répression politique (Éditions Syllepse, 2011). 